\title{
Impact of Corporate Social Responsibility Disclosures on Bankruptcy Risk of Vietnamese Firms
}

\author{
Soa La NGUYEN ${ }^{1}$, Cuong Duc PHAM${ }^{2}$, Anh Huu NGUYEN ${ }^{3}$, Hung The DINH ${ }^{4}$
}

Received: February 23, 2020 Revised: March 15, 2020 Accepted: April 03, 2020

\begin{abstract}
This study investigates the nexus between the level of Corporate Social Responsibility Disclosures (CSRD) and Risk of Bankruptcy of companies that are listing in the Stock Exchanges of Vietnam. To investigate that relationship, this study collected secondary data from annual audited financial statements from 2014 to 2018 of listing companies. Applying two different regression models with two dependent variables and six independent and control variables, we find out that Vietnamese firms with higher level of CSRD performance can rapidly reduce their risk of bankruptcy. This phenomenon happens in the current year and in the coming years in all firms in the research sample. This result may be that the disclosures of social responsibility information can bring financial and non-financial benefits to the firms. In addition, the results also point out that there is a difference in risk of bankruptcy between the group of companies, which discloses and the one which does not disclose corporate social responsibility on their annual reports. This might be from the effects of various factors such as business size, financial leverage, market to book ratio, return on assets, cash flow from operations, etc. Our research results can be applied to other firms in Vietnam and in other similar jurisdictions.
\end{abstract}

Keywords: Accounting Information, Bankruptcy Risk, Social Responsibility, Vietnam.

JEL Classification Code: A14, G33, M21

\section{Introduction}

The corporate social responsibility disclosures (CSRD) is a process of providing information on the environmental and social impacts of economic activities of companies to related parties. Based on this information, stakeholders can assess the level of social responsibility of enterprises. Many companies in the world have achieved certain results through

1. First Author. School of Accounting and Auditing, The National Economics University, Vietnam. Email: soanl@neu.edu.vn

2. Corresponding Author. Associate Professor, School of Accounting and Auditing, The National Economics University, Vietnam [Postal Address: 207 Giai Phong Road, Dong Tam Ward, Hai Ba Trung District, Hanoi, 116000, Vietnam] Email: cuongpd@neu.edu.vn

${ }^{3}$ Associate Professor, Dean, School of Accounting and Auditing, The National Economics University, Vietnam. Email:anhnh@neu.edu.vn

${ }^{4}$ Vice Dean, School of Accounting and Auditing, The National Economics University, Vietnam. Email: hungdt@neu.edu.vn

(c) Copyright: The Author(s)

This is an Open Access article distributed under the terms of the Creative Commons Attribution Non-Commercial License (http://Creativecommons.org/licenses/by-nc/4.0/) which permits unrestricted noncommercial use, distribution, and reproduction in any medium, provided the original work is properly cited. the practice and disclosures of CSR. For instance, Microsoft has become the leading prestigious technology company in the world according to Reputation Institute in 2012 with community support programs and charity programs. Another example is the revival of Nike after a sales slump due to accusations and lawsuits related to scandals involving Nike's suppliers exploiting workers with cheap wages. This issue revealed by the publicity of Nike's suppliers was monitored by non-governmental organizations in 2004. According to Spasić and Stojanović (2013), companies' pressure for accountability in reporting comes from various reasons including demands from pressure groups such as investors and consumers, and directives from United Nation's and European Community's (EU). Therefore, our research was conducted for raising awareness about the importance of CSRD of listed companies in Vietnam stock market and promotion for CSRD.

This study aims to evaluate the value of CSRD in the context of corporate financial distress. At the crux of the study is a simple question: Whether and how the likelihood of bankruptcy of financially-distressed firms can be reduced by their CSRD. In addition, the results also point out that, there is a difference in risk of bankruptcy between the group 
of companies that did not practice CSRD and the group of companies that did. This study does not only extend previous researches with the relationship between CSRD and risk of bankruptcy of the current year, but also considers the effect of CSRD performance to risk of bankruptcy in the next year. This finding is important for encouraging listed companies to practice and disclose CSR to meet the needs of stakeholders, reducing the financial risk and the risk bankruptcy in the future.

The remainder of the paper is structured as follows. Section 2 presents the Literature review. Section 3 describes Theoretical background and Research hypotheses. Section 4 presents our Sample and research methodology. Section 5 discusses the Findings and provides a conclusion.

\section{Literature Review}

The importance of the practice and publication of social responsibility information has recently received sustained attention from researchers around the world. These studies have argued that CSRD can improve the satisfaction of all stakeholders, enhance the corporate brand image, increase firm value, and lower the cost of capital. According to Lin and Dong (2018), firms with a history of positive corporate environmental performance are less likely to file for bankruptcy when they are in deep financial distress and are more likely to experience accelerated recovery from distress. According to Cai, Cui, and Jo (2016), firms with better CSRD are less risky, and provide evidence suggesting that corporate social responsibility is positively related to firm value. Similarly, Al-Hadi and Chatterjee (2019) shows that corporate social responsibility performance is associated with a positive valuation effect, and in their metaanalysis of prior quantitative research, Poddi and Vergalli (2016) conclude that there is a positive association between corporate social or environmental responsibility and corporate financial performance. According to Oikonomou, Brooks, and Brooks (2014) and Nguyen (2018), social responsibility maintenance can be seen as a manner in their business decisions and processes, along with the strength of their relationships with various corporate stakeholders.

Ghoul, Guedhami, Kwok, and Mishara (2011) and Vo and Bui (2018) found that resources used for improving responsible employee relations, environmental policies, and product strategies contributes substantially will reduce firms' cost of equity. Yeh, Lin, Wang, and Wu (2019) find evidence that Chinese firms with higher environmental responsibility performance can rapidly reduce their cost of debt, and expenditures for improving environmental responsibility performance towards investors make the greatest contribution to reducing firms' financing costs, and this effect is more significant in recessions than in economic booms. Cheng, Ioannou, and Serafeim (2013) report that firms with better environmental responsibility results will face significantly lower capital constraints. Similarly, some pioneer research also documents that strong environmental responsibility performance can lower the cost of equity capital (Oikonomou et al., 2014), cost of debt capital (Jha \& Cox, 2015), and credit spreads (Cheng et al., 2013). According to Ghoul et al. (2011), firms with better environmental responsibility performance exhibit cheaper equity financing and reducing firms' cost of equity. However, these studies have been carried out in developed countries where there are differences in business characteristics, characteristics of capital structure and financial market compared to Vietnam.

The importance of practicing CSRD in Vietnamese enterprises is also receiving increasing attention from both businesses and researchers. The research of Yang and Kim (2018) indicated that the level of disclosure of environmental accounting information affects positively the financial performance of businesses both now and in the future. The research of Nguyen and Tran (2019) investigates and reports that there is close relationship between the level of environmental accounting practices and corporate financial risk. Similarly, Ho, Ho, and Nguyen (2017) show that corporate social responsibility performance is associated with a positive effect, and there is a positive association between corporate social or environmental responsibility and corporate financial performance. According to Yang and Kim (2018), the disclosure levels of CSRD of Vietnamese firms tend to increase. However, these levels did not meet the demand for information on CSRD as expected by stakeholders. Eventhough the number of studies on CSRD is high, an empirical examination of the relationship between CSRD performance and cost of capital in the emerging markets context is limited. The lack of empirical studies on this issue could be one of the factors in explaining why companies listed on the Vietnam securities market are less concerned or involved in promoting their CSRD to various stakeholders. Upon the current study and practice of this issue in Vietnam, we found this is research gap for this study.

\section{Theoretical Background and Hypotheses}

\subsection{Theoretical Background}

Signaling theory is useful for describing behavior when two parties (individuals or entities) have access to different information sources. Typically, one party, the sender, must choose whether and how to communicate (or signal) that information, and the other party, the receiver, must choose how to interpret the signal. Accordingly, signaling theory holds a prominent position in a variety of management literatures, including strategic management, entrepreneurship, and human resource management (Connelly, Certo, Ireland, \& 
Reutzel, 2011). Mavlanova, Benbunan-Fich, and Koufaris (2012) argue that, when investors have more private information than others, information asymmetry occurs in the capital market. To reduce the cost of capital, corporations exert great effort at reducing the information asymmetry. Therefore, the lower information asymmetry in the capital market leads to the lower cost of capital (Walker, 2010).

The signal theory can offer one solution to information asymmetry. Mavlanova et al. (2012) use a signal timeline to explain the signaling process between the signaler and receiver. To reduce information asymmetry, the signaler conveys a signal to the receiver. After observing and interpreting the signal, he or she will make a decision and transmits it to the signaler. In this study, the signaler is a firm that conveys the Environmental Financial Accounting Practices (EFAP) as a signal to the receivers, who are investors. After receiving and interpreting this signal, the investors will make their investment decision and decide how much payment they require, which is the feedback. Mahoney, Thorne, Cecil, and LaGore (2013) suggests that EFAP can signal cooperation information, which links governments, businesses, and society, to investors. Hahn and Kühnen, (2013) find that firms transmit corporate governance related information to potential investors to reduce their information asymmetry and investment risk. Corporate executives can deliver non-financial messages to potential investors. Connelly et al. (2011) explain that EFAP performance can reduce firms' cost of capital through information transmission, such as signaling.

Companies with higher financial performance generally tend to disclose environmental accounting information (Nguyen \& Tran, 2019). Vietnamese firms are paying attention to the release of information on environmental indicators, but these have not been logically stated based on the assessments of stakeholders (Yoon \& Lee, 2019). Ho et al. (2017) indicate that there is a cognitive gap in EFAP regulation and standard references between developed markets and Vietnam. In 2015, the Ministry of Finance of Vietnam issued Circular 155/2015/TT-BTC on guidelines for information disclosure on securities market. In particular, Vietnamese firms listed on securities market are required to report the related impact of the company on the environment. Besides, Vietnamese firms are also encouraged to publish environmental information according to Global standards for sustainability reporting (Gri , 2016).

Stakeholder theory also relates to this research. It was first introduced by Freeman (1984) in his landmark book, "Strategic Management: A Stakeholder Approach". The theory suggests that shareholders are merely one of many stakeholders in one specific company. The stakeholder involves anyone invested and involved in, or affected by, the company including employees, environmentalists near the company's plants, vendors, governmental agencies, and more. Freeman's theory suggests that a company's real success lies in satisfying all its stakeholders, not just those who might profit from its stock.

\subsection{Hypothesis}

Stakeholder theory (Freeman, 1984) suggests that investing in social responsibility helps organizations reduce their risk of bankruptcy. By creating a corresponding source of capital among stakeholders, taking social responsibility provides organizations with a beneficial protection equivalent to an insurance policy. Public perception of a company that does not practice well social responsibility can increase the severe reaction. It increases the chances of a company for being held accountable and getting more negative results. Therefore, poor social and environmental responsibility can exacerbate costs at a time when companies face serious difficulties. In particular, the company may be pressured to control the damage to its image by spending heavily on advertising and public relations. Due to poor social responsibility, companies cannot maintain the loyalty of their customers and employees. Customers can switch to another providers and employees can leave the company when the hardship is taking place in the company.

Recent empirical studies have found a negative correlation between corporate social responsibility and corporate risk. The study of Monti, Pattitoni, Petracci, and Randl (2018) viewed that social responsibility is associated with reduced systematic risk. Research by Lin and Dong (2018) found a negative relationship between the advantages of social responsibility and systemic risk. If businesses pay more attention to issues related to community, employment and environmental issues, then risk of bankruptcy tends to decrease. Harjoto and Laksmana (2016) showed that improved environmental risk management is associated with lower capital costs and especially lower equity cost. Chakraborty, Luciasilva, and Sheikh (2018) state that managers tend to use social responsibility activities to ensure support from local communities and politicians, reducing the risk that businesses may encounter. The research conducted by Cai et al. (2016) found that environmentally-responsible firms experience lower risk. From that argument, the research proposes the first hypothesis as follows:

Hypothesis 1a: There is a negative relationship between CSRD performance and bankruptcy risk of the company in the current year.

Hypothesis 1b: There is a negative relationship between CSRD performance and bankruptcy risk of the company in the following year.

There is a lot of empirical support for the view that companies will be penalized if they see business management 
in ways that conflict with social values. This is true when the conflict arises between pursuing organizational profits and the goal of environmental protection. Thus, one of the ways that companies manage their risks of operating and improving financial performance is to engage in socially and socially responsible behavior. Cai et al. (2016) demonstrated that companies with environmental accounting disclosures would secure trust and image with stakeholders, thus reducing risk of bankruptcy. Monti et al. (2018) argued that when a company participates in social responsibility, it maximizes shareholder value, enhances its credibility, and ensures long-term viability. Therefore, investors and managers of companies must pay attention to CSR activities in developing their investment strategies and regulatory policies. From this point of view, the study proposes the second hypothesis as follows:

Hypothesis 2: There are differences in bankruptcy risk between the group of companies that does not practice CSRD and the group that does.

\section{Research Methodology}

\subsection{Data Collection}

Group 1: We choose a sample of companies which meet two criteria: (i) having a complete set of annual accounting data for the five years 2014-2018, and (ii) companies must disclose social responsibility information in their annual report or sustainability report. The final sample for this study was unbalanced table data, as shown in Table 1.

Group 2: Listed companies do not disclose social responsibility information: These companies must meet two criteria: (i) a complete annual accounting data sheet covering the five years (2014-2018) and ii) companies must be aligned to the size, sector and time of listing with Group 1 companies.

Although the number of companies selected for research is not large compared to the total number of companies listed on the Vietnam Stock Exchange at that time. However, with the binding of standards and the convenience of data collection, the research team used the above research data. The sample size chosen by the authors with 613 observations is satisfied to the research requirements (Tauchen, 1986; Hair, Christian, \& Sarstedt, 2014).

\subsection{Variable Measurements}

\subsubsection{Dependent Variable: Coefficient of Bankruptcy (Z-Score)}

Z-Score is a statistical measure that quantifies distance (measured by standard deviation) from any data point to the average of a data set. The coefficient of bankruptcy, also known as Z-Score by US economist Altman (Altman, Iwanicz-Drozdowska, Laitinen, \& Suvas, 2016). Formula for calculating the coefficient of bankruptcy risk:

$$
\text { Z-Score }=1,2 * A_{1}+1,4 * A_{2}+3,3 * A_{3}+0,6 * A_{4}+1,0 * A_{5}
$$

Where:

$\mathrm{A}_{1}=$ Working capital ((Current assets - Short-term liabilities) /Total assets)

$\mathrm{A}_{2}=$ Undistributed profits /Total assets

$\mathrm{A}_{3}=$ EBIT (Profit before interest and tax)/Total assets

$\mathrm{A}_{4}=($ Market price of shares $*$ Number of outstanding shares)/Total debts.

$\mathrm{A}_{5}=$ Effective use of assets (Revenue /Total assets)

If $Z>2.99$ : The enterprise is in a safe area, there is no risk of bankruptcy

If $1.8<\mathrm{Z}<2.99$ : The business is in the warning zone, there may be a risk of bankruptcy

If $Z<1.8$ : The business is in a dangerous area, the risk of bankruptcy is high.

\subsubsection{Independent Variable: Level of Corporate Social Responsibility Disclosures (CSRD)}

According to the Global Reporting Initiative's Sustainable Development Report Guidelines (2016), the total number of

Table 1: Research sample statistics

\begin{tabular}{|l|c|c|}
\hline & $\begin{array}{c}\text { Firm - year } \\
\text { observations }\end{array}$ & Distinct firms \\
\hline $\begin{array}{l}\text { Initial sample: Vietnam companies listed on the Vietnam Stock Exchange over } \\
\text { the period 2014 to 2018 }\end{array}$ & 1.005 & 150 \\
\hline Exclude: Firms provide less than two-year-information to calculate CSRD & $(251)$ & $(52)$ \\
\hline $\begin{array}{l}\text { Exclude: Firms do not provide enough financial accounting information to calculate } \\
\text { Z-Score }\end{array}$ & $(80)$ & $(19)$ \\
\hline $\begin{array}{l}\text { Exclude: Firms do not provide enough financial accounting information to calculate } \\
\text { control variables }\end{array}$ & $(61)$ & $\mathbf{( 1 6 )}$ \\
\hline Final sample & $\mathbf{6 1 3}$ & $\mathbf{6 3}$ \\
\hline
\end{tabular}

Source: Composer from http://finance.vietstock.vn 
items for disclosure of mandatory environmental accounting information is 34 items in the 12 relevant fields as shown in Table 2.

Depends on how the company has published relevant information on the annual report for assessing the scored for the level of corporate social responsibility disclosures (CSRD) according the Table 3.

CSRD is calculated according to the weighted approach, depending on the quality of the information provided to assess the score for each item, then averaged for each category and calculated CSRD. The formula is as follows: The level of corporate social responsibility of firms

$$
\mathrm{X}=\frac{\sum_{i=1}^{34} Y i}{40}
$$

Yi is the score of information item i published by firm X.

\subsubsection{Control Variables}

There have been various studies on the factors affecting the risk of bankruptcy such as Öztekin (2015), Nguyen (2018), Lee (2018), and Nguyen, Khuu, and Nguyen (2018).
These studies showed that many factors affecting the cost of capital, including financial leverage, return on asset, management competence, company size, cash flow, the ratio of the market value to book value, quick ratio, business cycle, listing period, independent auditing, etc. In order to examine the relationship between social responsibility practice and risk of bankruptcy, previous studies have also used control variables besides independent variables such as: the percentage of state capital, financial leverage, cash flow, the ratio of the market value to book value, debt ratio, and independent auditor (Nguyen, 2018; Godfrey, Merrill, \& Hansen, 2009; Oikonomou et al., 2014; and Yeh et al., 2019). These studies have demonstrated that those factors have significantly effect on firms' bankruptcy risks. Besides that, due to data collection limitations, this study will include five control variables to consider the relationship between EFAP and Z-Score including: Business Size (SIZE); Financial leverage (LEV); Market-to-book ratio (MTB); Return on assets (ROA); and Cash flow from operations (CFO).

To examine the relationship between CSRD and risk of bankruptcy, two following stage regressions are adopted to verify hypothesis 1 and 2 . These regressions employ a lag term to describe the current Vietnam's capital market, weak efficiency.

Table 2: Items for Mandatory Environmental Information Disclosure

\begin{tabular}{|c|l|c|c|l|c|}
\hline No. & \multicolumn{1}{|c|}{ Field } & Number of items & No. & Field & Number of items \\
\hline 1 & Employment & 3 & 11 & Rights of Indigenous Peoples & 1 \\
\hline 2 & Labor/Management Relation & 1 & 12 & Human Right Assessment & 3 \\
\hline 3 & Occupational Health and Safety & 10 & 13 & Local Communities & 2 \\
\hline 4 & Training and Education & 3 & 14 & Supplier Social Assessment & 2 \\
\hline 5 & Diversity and Equal Opportunity & 2 & 15 & Public Policy & 1 \\
\hline 6 & Non - Discrimination & 1 & 16 & Rights of Indigenous Peoples & 2 \\
\hline 7 & $\begin{array}{l}\text { Freedom of Association and } \\
8\end{array}$ & 1 & 17 & Marketing and Labeling & 3 \\
\hline 9 & Forced or Compulsory Labor & 1 & 18 & Customer Privacy & 1 \\
\hline 10 & Security Practices & 1 & 19 & Socioeconomic Compliance & \\
\hline
\end{tabular}

Source: Choosing from Gri Standards, 2016

Table 3: Method to assess the levels of environmental financial accounting practices

\begin{tabular}{|l|c|}
\hline \multicolumn{1}{|c|}{ Level of information disclosure } & Score \\
\hline Publication information is both quantitative and qualitative form & 4 \\
\hline Only qualitative, non - quantitative disclosure & 3 \\
\hline Quantitative information both in object and value, no qualitative information & 2 \\
\hline Quantitative information on the value, no object and no qualitative information & 1 \\
\hline No information disclosure & 0 \\
\hline
\end{tabular}




$$
\begin{aligned}
\text { Z-Score }_{\mathrm{jt}}= & \beta_{0}+\beta_{1} \mathrm{CSRD}_{\mathrm{jt}}+\beta_{2} \operatorname{SIZE}_{\mathrm{jt}}+\beta_{3} \mathrm{LEV}_{\mathrm{jt}}+\beta_{4} \mathrm{MTB}_{\mathrm{jt}}+ \\
& \beta_{5} \mathrm{ROA}_{\mathrm{jt}}+\beta_{6} \mathrm{CFO}_{\mathrm{jt}} \\
\text { Z-Score }_{\mathrm{jt}}= & \beta_{0}+\beta_{1} \mathrm{CSRD}_{\mathrm{jt}-1}+\beta_{2} \mathrm{SIZE}_{\mathrm{jt}}+\beta_{3} \mathrm{LEV}_{\mathrm{jt}}+ \\
& \beta_{4} \mathrm{MTB}_{\mathrm{jt}}+\beta_{5} \mathrm{ROA}_{\mathrm{jt}}+\beta_{6} \mathrm{CFO}_{\mathrm{jt}}
\end{aligned}
$$

\section{Results and Discussion}

\subsection{Descriptive Statistics}

During the study period from 2014 to 2018, increasing market volatility is not only evidenced by the number of listed companies with disclosure of social responsibility information, but also by indicator level of social responsibility disclosures, which is a good sign demonstrating that Vietnam firms are paying more attention to corporate social responsibility disclosures.

Table 4 presents a basic statistical description of independent variables and dependent variables.

\subsection{Evaluation of Correlation of Variables}

Table 5 presents the results of the correlation coefficient test between the variables and the results of the multicollinearity test. The level of corporate social responsibility disclosures is negatively correlated with risk of bankruptcy, which means that the higher the level of corporate social responsibility disclosures, the lower risk of bankruptcy. However, to confirm whether the results are accurate we need to conduct multivariate regression analysis.
Table 5 also shows the results of the multicollinearity test. The results show that, at the same time, the correlated pairs are less than 0.8 and the VIF of the independent variable is less than 5 , which proves that there is not multicollinearity between variables. In addition, in order to increase the reliability of the regression results, the study conducted to examine whether there was a change in variance in the research model through the use of the White's General test. The test results show that the $\mathrm{p}$ value is greater than 0.05 , so with a significance level of $5 \%$ the $\mathrm{H} 0$ hypothesis on the uniformity of the variance is acceptable. That is, the pattern does not exist in the phenomenon of variance. With the above analysis, we assert that appropriate research data to perform multivariate regression analysis to examine the relationship between the level of corporate social responsibility disclosures and risk of bankruptcy.

\subsection{Research Finding and Discussions}

(1) The relationship between the level of corporate social responsibility disclosures and the bankruptcy risk of the current year.

Table 6 presents the results of regression using the least squares (OLS), Fixed effects model (FEM) and Random effects model (REM). The results show that there are differences between the three methods. Therefore, to conclude what results should be used, the research conducted two following tests: Step 1: Use Hausman test to decide to use whether FEM or REM method. The $p$ value of Hausman

Table 4: Statistical Analysis

\begin{tabular}{|l|c|c|c|c|c|c|c|c|}
\hline & Z-Score & CSRD $_{\mathbf{t}}$ & CSRD $_{\mathbf{t}-1}$ & SIZE & LEV & MTB & ROA & OFO \\
\hline Number of Observations & 613 & 613 & 415 & 613 & 613 & 613 & 613 & 613 \\
\hline Mean value & 3.817 & 2.132 & 1.328 & 15.012 & 0.317 & 3.016 & 0.192 & 0.072 \\
\hline Standard Deviation & 3.214 & 2.201 & 1.429 & 9.215 & 0.410 & 4.154 & 1.037 & 0.182 \\
\hline Minimum value & 1.523 & 0.000 & 0.000 & 10.152 & 0.281 & 0.208 & -0.241 & -0.241 \\
\hline Maximum value & 4.243 & 3.318 & 3.509 & 19.729 & 0.816 & 20.192 & 0.893 & 1.310 \\
\hline
\end{tabular}

Table 5: Correlation and Multicollinearity test

\begin{tabular}{|l|c|c|c|c|c|c|c|c|}
\hline & Z-Score & CSRD & SIZE & LEV & MTB & ROA & OFO & VIF \\
\hline Z-Score & 1.000 & & & & & & & - \\
\hline CSRD & -0.216 & 1.000 & & & & & & 1.210 \\
\hline SIZE & -0.176 & 0.105 & 1.000 & & & & & 2.054 \\
\hline LEV & -0.209 & 0.267 & 0.189 & 1.000 & & & & 2.172 \\
\hline MTB & -0.023 & 0.054 & 0.176 & -0.210 & 1.000 & & & 2.097 \\
\hline ROA & -0.726 & 0.310 & 0.267 & -0.189 & 0.154 & 1.000 & & 2.132 \\
\hline OFO & -0.318 & 0.201 & 0.165 & -0.254 & 0.217 & 0.173 & 1.000 & 2.067 \\
\hline
\end{tabular}


test is 0.000 , therefore the FEM model is more appropriate. Step 2: Use the F-test to select the result between the FEM or OLS method. The result of the $\mathrm{p}$ value of $\mathrm{F}$-test is 0.000 , so the FEM model is more appropriate. Thus, the final fit model to measure this relationship is the pooled FEM model, with a 5\% significance level. The results in Table 6, (Sig. $=0.0297<0.05$ ) show that the level of corporate social responsibility disclosures affects the current year's Z-Score.

Table 6: Regression Results - the case does not consider latency factor

\begin{tabular}{|l|c|c|c|}
\hline \multirow{2}{*}{} & \multicolumn{3}{|c|}{ Z-Score } \\
\cline { 2 - 4 } & OLS & FEM & REM \\
\hline \multirow{2}{*}{ CSRD $_{\mathrm{t}}$} & -0.340 & -0.234 & -0.386 \\
& $(.0210)$ & $(.0297)$ & $(.0209)$ \\
\hline \multirow{2}{*}{ SIZE } & -0.309 & -0.376 & 0.387 \\
& $(.0023)$ & $(.0019)$ & $(.0093)$ \\
\hline \multirow{2}{*}{ LEV } & -0.512 & 0.318 & -0.317 \\
& $(.0032)$ & $(.0029)$ & $(.0056)$ \\
\hline \multirow{2}{*}{ MTB } & -0.423 & -0.304 & -0.130 \\
& $(.0054)$ & $(.0031)$ & $(.0180)$ \\
\hline \multirow{2}{*}{ ROA } & -0.876 & -0.230 & -0.438 \\
& $(.0120)$ & $(.0018)$ & $(.0110)$ \\
\hline \multirow{2}{*}{ OFO } & -0.257 & -0.310 & -0.298 \\
& $(.0316)$ & $(.0180)$ & $(.0197)$ \\
\hline Number of Obs & 613 & 613 & 613 \\
\hline Constant & 0.298 & 0.310 & 0.276 \\
\hline Adj R - squareds & 0.2176 & 0.3198 & 0.3260 \\
\hline
\end{tabular}

The results in Table 6 also show that the relationship between the level corporate social responsibility disclosures and the bankruptcy risk is the reverse relationship (the coefficient between this relationship is -0.234). The results of this research comply with the previous studies such as Cai et al. (2016) and Oikonomou et al. (2012). This suggests that the higher the level of corporate social responsibility disclosures, the lower the likelihood of a business experiencing the financial risk of current year.

(2) The relationship between the level of corporate social responsibility disclosures and the financial risk of the following year.

To examine the relationship between the corporate social responsibility disclosures and the financial risk of the following years, the study performed a multivariate regression analysis with dependent variables: Z-Score and t-test. The results of the regression analysis are presented in Table 7. For the results of the Breusch-Pagan Lagrange test, the accepted hypothesis $\mathrm{H}_{0}($ Prob $=1.0000)$ thus the pooled OLS model is more appropriate than the REM model.
For the Hausman test, rejecting the hypothesis $\mathrm{H}_{0}$ (Prob $=$ 0.0187) means that the FEM model is more appropriate than the REM model. However, based on F-test results (Prob= 0.3012), it is also assumed that the fit model is pooled OLS. Thus, the final fit model to measure this relationship is the pooled OLS model, with a 5\% significance level. The results in Table $8,(\mathrm{Sig} .=0.0321<0.05)$ show that there is a relationship between the level corporate social responsibility disclosures and bankruptcy risk of the following year.

Table 7: Regression Results - The case considers the latency factor

\begin{tabular}{|l|c|c|c|}
\hline \multirow{2}{*}{} & \multicolumn{3}{|c|}{ Z-Score } \\
\cline { 2 - 4 } & OLS & FEM & REM \\
\hline \multirow{2}{*}{ CSRD $_{\mathrm{t}-1}$} & -0.324 & -0.268 & -0.318 \\
& $(.0321)$ & $(.0210)$ & $(.0278)$ \\
\hline \multirow{2}{*}{ SIZE } & -0.352 & -0.587 & 0.312 \\
& $(.0013)$ & $(.0047)$ & $(.0068)$ \\
\hline \multirow{2}{*}{ LEV } & -0.317 & 0.087 & -0.376 \\
& $(.0031)$ & $(.0287)$ & $(.0031)$ \\
\hline \multirow{2}{*}{ MTB } & -0.298 & -0.209 & -0.219 \\
& $(.0029)$ & $(.0032)$ & $(.0198)$ \\
\hline \multirow{2}{*}{ ROA } & -0.867 & -0.310 & -0.319 \\
& $(.0027)$ & $(.0087)$ & $(.0109)$ \\
\hline \multirow{2}{*}{ OFO } & -0.287 & -0.319 & -0.198 \\
& $(.0319)$ & $(.0328)$ & $(.0318)$ \\
\hline Number of Obs. & 415 & 415 & 415 \\
\hline Constant & 0.428 & 0.319 & 0.429 \\
\hline Adj R ${ }^{2}$ & 0.2876 & 0.3287 & 0.3180 \\
\hline
\end{tabular}

The results in Table 8 also show that the relationship between the level of disclosure of environmental accounting information and the bankruptcy risk is the reverse relationship (the coefficient between this relationship is -0.324). This suggests that the higher the level of corporate social responsibility disclosures, the lower the likelihood of a business experiencing the risk of bankruptcy of following year.

(3) Considering the risk of bankruptcy between the company that did disclose the social responsibility information and the company that did not.

The study examined the difference in the risk of bankruptcy between the two groups of companies: the group that disclosed social responsibility information and the group that did. The results are presented in Table 8, which shows the bankruptcy risk of each group and the results of the t-test.

The mean value of risk of bankruptcy for group statistics of listed companies with social responsibility disclosures (3.0982) is higher than the companies that do not disclose environmental accounting information (1.9087). At the same 
Table 8: Group risk of bankruptcy and Bartlett's test for equal variances

\begin{tabular}{|c|l|c|c|c|c|}
\hline & \multicolumn{1}{|c|}{ Group } & No & Mean & Std.Dev & Std.Err \\
\hline \multirow{3}{*}{ Z-Score } & CSRD & 63 & 3.0982 & 1.4326 & 0.05342 \\
\cline { 2 - 6 } & Non - CSRD & 63 & 1.9087 & 1.2346 & 0.12187 \\
\hline
\end{tabular}

\begin{tabular}{|l|c|c|c|c|c|c|c|}
\hline & F & \multirow{2}{*}{ Prob>F } & SS & \multirow{2}{*}{ df } & \multirow{2}{*}{ MS } & \multicolumn{2}{|c|}{ Bartlett's test } \\
\cline { 5 - 8 } & & & & & & X2 & Prob \\
\hline Z-Score & 0.47 & 0.0000 & 10.109 & 243 & 2.178 & 101.1365 & 0.000 \\
\hline
\end{tabular}

time, t-test results show that $\mathrm{p}$-value $=0.000<0.05$. Thus, the hypothesis $\mathrm{H}_{0}$ is rejected and accepts the alternative hypothesis. This means that there is a statistically significant difference in Z-Score between listed companies with social responsibility information disclosure and listed companies without disclosure of social responsibility information.

Thus, when the listed companies disclose social responsibility information in a detailed and transparent manner they will avoid the likelihood of the risk of bankruptcy, as well as enhances the image, increases the value of the brand, promotes morale of employees, and increases productivity labor, resulting in reduced transaction costs to obtain external funding.

\section{Conclusion and Recommendation}

The research results indicate the importance of social responsibility disclosure of enterprises in the long-term business strategy. The corporate's social responsibility disclosure is not only to enhance financial performance, but also avoidable bankruptcy risk. Highly effective firms are often among the top firms in the industry that are wellregarded for their social responsibility, as demonstrated by adequate and detailed disclosure of information related to the social. The disclosure of social responsibility information is a way for businesses to enhance their image and reputation with stakeholders, especially in the integration trend when developed countries are very interested in green growth and sustainable development. However, the situation shows that the accounting work and information disclosure related to the social have not attracted enough attention by Vietnamese firms. Therefore, in the future, businesses need to strengthen their solution to improve the accounting practices to support the disclosure of information. From the research results, the research team proposed some recommendations to Vietnamese firms as follows:

First, the need to raise awareness of corporate social responsibility and the benefits of disclosing detailed social responsibility information to the risk of bankruptcy of the business. Some businesses say that, if they focus on environmental protection activities, transparency of social responsibility information is costly, reducing profits; it is a misconception. The results of this study show that the firms with higher CSRD performance have a higher Z-Score for both current year and the following year. Therefore, the practice and disclosure of social information is necessary, helps businesses avoid legal complications to improve the image and reduces experiencing risk of bankruptcy.

Second, the results also show that, in addition to the level of disclosure of social responsibility information, there are other factors including business size, financial leverage, market-to-book ratio, return on assets, and cash flow from operations. Therefore, in order to avoid the risk of bankruptcy, beside the factors of practice and information disclosure, enterprises should consider the influence of other factors on the risk of bankruptcy. Since then, there is a reasonable adjustment plan to improve the efficiency of capital use, bringing the highest economic efficiency to businesses.

Basing on the quantitative and qualitative research methodology, the team assessed the impact of the level of social responsibility disclosures on the bankruptcy risk of the business. The results indicate that the social responsibility disclosures affect the bankruptcy risk of businesses both now and in the future. At the same time, the study also found a relative difference in bankruptcy risk between two groups of enterprises, those that do social responsibility disclosure and those that do not. From the research results, this study has made several recommendations to promote the accounting practices in the future. The paper has enriched the sources of research on social responsibility disclosures as well as contributed to the disclosure of social responsibility information in the future. However, research is limited to one bankruptcy risk measures and five control variables, while still using other indicators to test this relationship, further limiting the sample also makes sense dependency of affected results. Nevertheless, we consider these to be suggestive for further research in the future.

\section{References}

Al-Hadi, A., \& Chatterjee, B. (2019). Corporate Social Responsibility Performance, Financial Distress and Firm Life Cycle: Evidence from Australia. Accounting and Finance, 59(2), 961-989. DOI:10.1111/acfi.12277. 
Altman, E. I., Iwanicz-Drozdowska, M., Laitinen, E. K., \& Suvas, A. (2016). Financial Distress Prediction in an International Context: A Review and Empirical Analysis of Altman's Z-Score Model. Journal of International, Financial Management and Accounting, 28(2), DOI: org/10.1111/jifm.12053

Cai, L., Cui, J., \& Jo, H. (2016). Corporate Environmental Responsibility and Firm Risk. Journal of Business Ethics, 139(3), DOI: 10.1007/s10551-015-2630-4.

Chakraborty, A., Luciasilva, \& Sheikh, S. A. (2018). Managerial Risk Taking Incentives, Corporate Social Responsibility and Firm Risk. Journal of Economics and Business, 101(1), 58-72. DOI: 10.1016/j.jeconbus.2018.07.004

Cheng, B., Ioannou, I., \& Serafeim, G. (2013). Corporate social responsibility and access to finance. Strategic Management Journal, 35(1), 1-23. DOI:org/10.1002/smj.2131

Connelly, B. L., Certo, S. T., Ireland, R. D., \& Reutzel, C. R. (2011). Signaling Theory: A Review and Assessment. Journal of Management, 37(1), 39-67. DOI: org/10.1177\%2F0149206310388419

Freeman, R. E. (1984). Strategic Management: A Stakeholder Approach. Boston, MA: Pitman

Ghoul, S. E., Guedhami, O., C.Y.Kwok, C., \& Mishara, D. R. (2011). Does corporate social responsibility affect the cost of capital. Journal of Banking \& Finance, 35(1), 2388-2406. DOI: 10.1016/j.jbankfin.2011.02.007

Gri. (2016). Gri standards. Retrieve March 10, 2020, from https:// www.globalreporting.org/Pages/default.aspx

Godfrey, P. C., Merrill, C. B., \& Hansen, J. M. (2009). The relationship between corporate social responsibility and shareholder value: An empirical test of the risk management. Strategic Management Journal, 30(4), 425-445. DOI:10.1002/ smj. 750

Hahn, R., \& Kühnen, M. (2013). Determinants of sustainability reporting: a review of results, trends, theory, and opportunities in an expanding field of research. Journal of Cleaner Production, 59(15), 5-21. DOI: org/10.1016/j.jclepro.2013.07.005

Hair F. J., Christian M. R., \& Sarstedt., M. (2014). PLS-SEM: Indeed, a Silver Bullet. Journal of Marketing Theory and Practice, 19(2), 139-152 DOI: org/10.2753/MTP1069-6679190202

Harjoto, M. A., \& Laksmana, I. (2016). The Impact of Corporate Social Responsibility on Risk Taking and Firm Value. Journal of Business Ethics, 151(2018), 353-373. DOI: 10.1007/s10551016-3202-y

Ho, V. T., Ho, T. V. A., \& Nguyen, T. C. (2017). The corporate environmental responsibility and corporate financial performance: evidences from Vietnamese listed companies. Paper presented at the International conference of University of Economic Ho Chi Minh City: Policies and sustainable economic development, HCMC, Vietnam, September 28, 2017.

Jha, A., \& Cox, J. (2015). Corporate social responsibility and social capital. Journal of Banking \& Finance, 60(1), 252-270. DOI: org/10.1016/j.jbankfin.2015.08.003
Lee, W. J. (2018). Group-affiliated Firms and Corporate Social Responsibility Activities. Journal of Asian Finance, Economics and Business, 5(4), 127-133. http://doi.org/10.13106/ jafeb.2018.vol5.no4.127

Lin, K. C., \& Dong, X. (2018). Corporate social responsibility engagement of financially distressed firms and their bankruptcy likelihood. Advances in Accounting, 43(1). DOI: org/10.1016/j. adiac.2018.08.001

Mahoney, L. S., Thorne, L., Cecil, L., \& LaGore, W. (2013). A research note on standalone corporate social responsibility reports: Signaling or greenwashing? Critical Perspectives on Accounting, 24(4-5), 350-359. DOI: org/10.1016/j. cpa.2012.09.008

Mavlanova, T., Benbunan-Fich, R., \& Koufaris, M. (2012). Signaling theory and information asymmetry in online commerce. Information \& Management, 49(5), 240-247. DOI: org/10.1016/j.im.2012.05.004

Monti, A., Pattitoni, P., Petracci, B., \& Randl, O. (2018). Does Corporate Social Responsibility Impact Risk? SSRN Electronic Journal. Retrieved March 10, 2020, from https://papers.ssrn.com/ sol3/papers.cfm?abstract_id $=3167883$.

Nguyen, T. T. (2018). Large Shareholders and Firm Value: Interaction between Power and Incentive to Expropriate. Journal of Economics and Development, 20(2), 65-93. DOI: 10.33301/JED-P-2018-20-02-04

Nguyen, L. S., \& Tran, M. D. (2019). Disclosure levels of environmental accounting information and financial performance: The case of Vietnam. Management Science Letters, 9(4), 557-570. DOI: 10.5267/j.msl.2019.1.007

Nguyen, T. H., Khuu, T. Q., \& Nguyen, N.D.L. (2018). Determinants of Firm Growth: Evidence from Vietnamese Small and Medium Sized Manufacturing Enterprises. Journal of Economics and Development, 20(3), 71-87. DOI: 10.33301/ JED-P-2018-20-03-05

Oikonomou, I., Brooks, C., \& Brooks, C. (2014), The Effects of Corporate Social Performance on the Cost of Corporate Debt and Credit Ratings. Financial Review, 49(1), 49-75. DOI: org/10.1111/fire.12025

Öztekin, Ö. (2015), Capital Structure Decisions around the World: Which Factors Are Reliably Important? Journal of Financial and Quantitative Analysis, 50(3), 301-323. DOI: org/10.1017/ S0022109014000660

Poddi, N. C. L., \& Vergalli, S. (2016). Corporate Social Responsibility and Firms' Performance: A Strategic Graphical Analysis. Journal of International Business and Economics, 4(1), 1-12. DOI: 10.15640/jibe.v4n1a1

Spasić, D., \& Stojanović, M. (2013). Sustainability repoerting theoretical framework and practice in the serbian oil industry. Economics and Organization, 10(3), 231-244. DOI: UDC 665.6/.7:005.71]:651.78

Tauchen, G. (1986). Finite state markov-chain approximations to univariate and vector autoregressions. Economics letters, 20(2), 177-181. DOI: org/10.1016/0165-1765(86)90168-0 
Vo, T.TA., \& Bui, P.N.K. (2018). Impact of Board Gender Diversity on Firm Value: International Evidence. Journal of Economics and Development, 19(1), 65-76. DOI: $10.33301 / 2017.19 .01 .05$

Walker, K. (2010). A Systematic Review of the Corporate Reputation Literature: Definition, Measurement, and Theory. Corporate Reputation Review, 12(4), 357-387.

Yang, H. C., \& Kim, Y. E. (2018). The Effects of Corporate Social Responsibility on Job Performance: Moderating Effects of Authentic Leadership and Meaningfulness of Work. Journal of Asian Finance, Economics and Business, 5(3), 121-132. http://doi.org/10.13106/jafeb.2018.vol5.no3.121

Yeh, C. C., Lin, F., Wang, T.-S., \& Wu, C.-M. (2019). Does corporate social responsibility affect cost of capital in China. Asia Pacific Management Review. DOI: org/10.1016/j.apmrv.2019.04.001

Yoon, B., \& Lee, J. H. (2019). Corporate Social Responsibility and Information Asymmetry in the Korean Market: Implications of Chaebol Affiliates. Journal of Asian Finance, Economics and Business, 6(1), 21-31. http://doi.org/10.13106/jafeb.2019. vol6.no1.21 